\title{
THE ROLE OF READING ROOM AT PGSD UNIVERSITAS SEBELAS MARET IN SUPPORTING THESIS PROCESS FOR STUDENTS
}

\section{Eli Sari Utami, Pulung Ardianto, Miftakhus Salami, Laras Mahmudah}

Universitas Sebelas Maret

larasmahmudah2@gmail.com

\section{Article History}

accepted 30/09/2018

approved $12 / 10 / 2018$

published $30 / 10 / 2018$

\section{Keywords}

Role, Reading Room, Thesis Preparation

\begin{abstract}
The Reasearch aims to determine the role of Kebumen VI Campus PGSD reading room in supporting the thesis-making process. It uses qualitative methods with data collection techniques through interviews, observation and documentation studies. The results show that the PGSD reading room Campus VI kebumen is intended to provide facilities in the form of printed and non-printed literature, as well as clinic consultation on how to track journals subscribed by the UNS Library.
\end{abstract}

Social, Humanities, and Education Studies (SHEs): Conference Series https://jurnal.uns.ac.id/shes 


\section{PENDAHULUAN}

Pembelajaran pada perguruan tinggi dapat dikatakan sukses apabila tujuan yang diembannya tercapai dengan baik. Tujuan dari pembelajaran di perguruan tinggi tertuang dalam tiga poin Tri Dharma Perguruan Tinggi yang terdiri dari pendidikan dan pengajaran, penelitian dan pengembangan, serta pengabdian masyarakat. Ketiga poin ini merupakan indikator yang harus dicapai perguruan tinggi dalam dunia pendidikan tinggi.

Salah satu poin dari Tri Dharma perguruan tinggi tersebut yang gencar digaungkan adalah penelitian. Hal tersebut karena penelitian dalam sebuah perguruan tinggi mempunyai dampak yang positif bagi perguruan tinggi yang menaunginya. Dampak positif ini dengan kata lain dapat disebut dengan keuntungan. Perguruan tinggi dapat memperoleh keuntungan apabila civitas akademika dalam perguruan tinggi tersebut dapat menghasilkan banyak penelitian yang berkualitas dan dapat dipublikasikan dalam jurnal-jurnal penelitian baik nasional maupun internasional. Keuntungan tersebut diantaranya adalah menaikkan reputasi perguruan tinggi, serta menumbuhkan kreatifitas dan inovasi di kalangan civitas akademika, serta dapat menghasilkan pemecahan masalah yang terjadi di lingkungan masyarakat sehingga dapat diterapkan kembali di lingkungannya menjadi suatu pengabdian masyarakat.

Dapat dikatakan bahwa penelitian berada pada posisi tengah dalam tiga poin Tri Dharma Perguruan Tinggi. Hal ini karena penelitian merupakan poin lanjutan dari poin pendidikan dan pengajaran yang di dalamnya mahasiswa dan civitas akademik, dibekali dengan berbagai teori. Teori inilah yang merupakan landasan dalam melakukan penelitian. Setelah teori ini diterapkan dalam proses penelitian dan menghasilkan pemecahan permasalahan yang terjadi di lingkungan masyarakat, maka penelitian ini tentunya layak untuk diaplikasikan dalam lingkungan masyarakat sebagai bentuk pengabdian masyarakat dari perguruan tinggi. Hasil penelitian ini tentunya sangat berperan penting dan strategis dalam menentukan keunggulan kompetitif dan pertumbuhan ekonomi suatu bangsa.

Mahasiswa yang menempuh program sarjana minimal akan melakukan satu kegiatan penelitian untuk keperluan penyusunan tugas akhir yang disebut skripsi. Pada proses penelitian untuk keperluan skripsi tentunya dibutuhkan berbagai sumber informasi atau referensi yang memang relevan dan kredibel oleh para peneliti yang dalam hal ini adalah mahasiswa program sarjana tingkat akhir. Referensi yang dibutukan meliputi buku-buku bacaan yang relevan, jurnal nasional dan internasional, serta hasil-hasil penelitian yang telah dipublikasikan di jurnal-jurnal penelitian.

Salah satu unit pelaksana teknis yang ditugaskan untuk menyediakan sumber informasi dalam mendukung proses penelitian di perguruan tinggi adalah Perpustakaan Perguruan Tinggi (Berawi, 2012:49). Perpustakaan perguruan tinggi ini memang dirancang untuk mendukung Tri Dharma Perguruan Tinggi yang diemban oleh Perguruan Tinggi (Kurniawan, 2016:239-240). Sebagai kampus wilayah terjauh dari pusat, Kampus PGSD Kebumen mempunyai fasilitas Ruang Baca sebagai tangan panjang dari Perpustakaan Perguruan Tinggi yang ada di kampus pusat. Walaupun bukan merupakan perpustakaan Perguruan Tinggi sebagaimana mestinya, Ruang Baca PGSD Kebumen menyediakan berbagai jenis layanan yang diperuntukkan bagi seluruh warga kampus termasuk mahasiswa. Diantara banyaknya layanan yang tersedia di ruang baca tersebut, terdapat salah satu layanan referen yang di dalamnya memang menghimpun berbagai hasil karya penelitian. Adapun yang bertugas untuk memberikan pelayanan pada layanan referen ini adalah pustakawan referen.

Dalam artikel ilmiah ini akan dipaparkan lebih mendalam mengenai peran ruang baca PGSD FKIP UNS Kampus VI Kebumen dalam mendukung proses penyusunan skripsi mahasiswa tingkat akhir. Peran ruang baca tersebut dilihat dari ketersediaan bahan bacaan yang dibutuhkan untuk referensi, peran pustakawan dalam pencarian literatur dan akses mahasiswa terhadap kebutuhan akan jurnal dan literasi digital. 


\section{METODE}

Penelitian ini menggunakan desain penelitian kualitatif dengan jenis penelitian deskriptif dan metode penelitian jenis deskriptif interpretatif. Penulis menganalisis secara detail data yang terkumpul mengenai peran Ruang Baca PGSD Kampus VI Kebumen dalam mendukung proses penyusunan skripsi, kemudian dilakukan interpretasi data. Informasi yang diperoleh dianalisis dengan cara melakukan penafsiran terhadap obyek yang diteliti berdasarkan data yang diperoleh kemudian diambil kesimpulan.

Teknik pemilihan informan yang digunakan adalah menggunakan metode probability sampling dengan teknik purposive sampling yaitu memilih informan berdasarkan tujuan atau kriteria tertentu. Kriteria tersebut adalah informan merupakan Mahasiswa PGSD Kampus VI Kebumen yang sedang dalam proses penyusunan skripsi, kerap memanfaatkan Ruang Baca untuk mendukung penyusunan skripsinya serta bersedia berparisipasi dalam penelitian ini dan dapat memberikan informasi yang berakitan dengan penelitian. Berdasarkan kriteria tersebut peneliti memilih 10 orang mahasiswa. Teknik pengumpulan data yang digunakan adalah observasi non partisipan, wawancara semi terstruktur dengan jenis wawancara mendalamdan studi dokumentasi.

Pada proses analisis data, penulis menggunakan tiga alur kegiatan yang terjadi secara bersamaan yaitu reduksi data, penyajian data dan penarikan kesimpulan. Upaya yang dilakukan penulis dalam menjaga keabsahan data penelitian adalah dengan melakukan triangulasi sumber yaitu membandingkan data hasil pengamatan dengan data hasil wawancara dan membandingkan hasil wawancara dengan isi suatu dokumen.

\section{HASIL DAN PEMBAHASAN \\ Koleksi Ruang Baca PGSD FKIP UNS Kampus VI Kebumen}

Sebagai pemegang peran pendukung suksesnya mencapai tri dharma perguruan tinggi khususnya penelitian dan pengembangan, perpustakaan atau ruang baca seyogyanya memiliki koleksi bahan bacaan yang memadai. Koleksi tersebut dapat berupa buku pendukung atau handbook mata kuliah, kamus, ensiklopedi, buku fiksi, buku ilmiah, dan berbagai koleksi lainnya. Disampaikan dalam buku pedoman Perpustakaan Perguruan Tinggi yang diterbitkan oleh dikti bahwa perpustakaan atau ruang baca pada Perguruan Tinggi wajib menyediakan $80 \%$ dari bahan bacaan wajib mata kuliah yang ditawarkan di Perguruan Tinggi (Tsabit, 2008:87-88). Hal tersebut mengindikasikan bahwa kelengkapan literasi cetak berupa buku bacaan sangat perlu diperhatikan pada setiap perpustakaan atau ruang baca Perguruan Tinggi.

Berangkat dari teori tersebut, peneliti telah melakukan wawancara terhadap 10 orang mahasiswa PGSD FKIP UNS Kampus VI Kebumen (selanjutnya disebut dengan PGSD) yang menjadi sampel penelitian dan studi dokumentasi terhadap buku-buku yang terdapat di ruang baca PGSD. Data hasil wawancara menunjukkan bahwa ruang baca PGSD telah berhasil menyediakan buku literatur yang dibutuhkan oleh mahasiswa tingkat akhir untuk proses penyusunan skripsi. Semua responden menyatakan adanya buku-buku di ruang baca PGSD cukup untuk mendukung bahan penyusunan skripsi. Jika dibuat persentase ketersediaan buku bacaan di ruang baca PGSD mencapai angka 70\%. Angka tersebut jika dibuat rincian lebih detail berdasarkan jenis penelitian dari skripsi yang disusun oleh mahasiswa PGSD diperoleh angka 90\% untuk skripsi dengan jenis penelitian PTK (Penelitian Tindakan Kelas). Hal tersebut dikarenakan pengadaan buku untuk jenis penelitian PTK sudah diadakan sejak dahulu awal berdirinya ruang baca PGSD. Selain itu, jenis penelitian skripsi mahasiswa sebagian besar adalah PTK sehingga pengadaan buku untuk jenis penelitian ini jelas lebih banyak. Angka yang cocok untuk menyatakan ketersediaan buku sumber bagi skripsi dengan jenis penelitian kualitatif justru berbanding terbalik 
dengan buku sumber untuk skripsi dengan jenis penelitian PTK. Ketersediaan buku sumber untuk mendukung skripsi dengan jenis penelitian kualitatif hanya mencapai angka $30 \%$. Hal tersebut terjadi karena jenis penelitian ini merupakan hal baru bagi mahasiswa sehingga pengadaan buku sumber masih belum mencukupi. Sementara dalam mendukung skripsi dengan jenis penelitian kuantitatif berada di level tengahtengah antara jenis penelitian PTK dan kualitatif, yakni $50 \%$. Walaupun kuantitatif adalah jenis penelitian baru bagi skripsi mahasiswa, ketersediaan buku sumber untuk jenis penelitian ini cukup banyak karena berkaitan dengan mata kuliah mahasiswa yaitu statistika dan metodologi penelitian. Koleksi buku yang mendukung proses penyusunan skripsi tersebut meliputi buku-buku yang berkaitan dengan metodologi penelitian dan ilmu pendidikan dasar.

\section{Akses Jurnal, Literasi Digital dan Pelayanan Pustakawan}

Sumber informasi lain yang mendukung proses penyusunan skripsi adalah jurnal nasional dan internasional serta penelitian yang relevan. Dalam kaitannya dengan akses jurnal dan penelitian yang relevan, seluruh responden menyatakan bahwa ruang baca PGSD memberikan pelayanan yang memuaskan. Hal tersebut dikarenakan adanya fasilitas hotspot di ruang baca PGSD yang dapat diakses secara terbuka oleh seluruh mahasiswa. Setiap mahasiswa bebas menggunakan fasilitas hotspot selama jam kerja. Mulai dari pukul 07.30 hingga pukul 18.00 fasilitas hotspot dapat dinikmati oleh mahasiswa di dalam area ruang baca PGSD yang nyaman. Akan tetapi, di luar jam kerja tersebut mahasiswa juga masih bisa menikmati hotspot untuk mengunduh jurnal nasional dan internasional atau penelitian yang relevan sesuai dengan yang dibutuhkan karena jaringan hotspot tidak hanya terdapat di dalam ruang baca tetapi juga terdapat di luar ruang baca. Berkenaan dengan pencarian sumber terpercaya untuk mengunduh jurnal dan penelitan relevan yang telah dipublikasikan secara online, ruang baca PGSD memiliki pustakawan yang ramah yang siap membantu mahasiswa dalam mencari jurnal dan penelitian relevan atau yang lebih akrab dengan sebutan literasi digital. Ruang baca PGSD juga dilengkapi dengan sistem OPAC (Online Public Access Catalogue) yang memudahkan mahasiswa dalam melakukan pencarian literasi dari koleksi yang tersedia di ruang baca. Banyaknya deretan buku-buku dengan berbagai judul tentu membutuhkan waktu yang lama untuk menemukan buku yang diperlukan. Guna memudahkan hal tersebut mahasiswa dapat menggunakan sistem OPAC dengan langkah memasukkan judul atau nama pengarang koleksi yang dicari pada laman yang disediakan. Lalu, akan muncul daftar pilihan koleksi yang tersedia di ruang baca PGSD. Setelah menemukan buku yang dicari mahasiswa mencarinya sesuai dengan katalog di rak buku yang tersedia.

Dalam kaitannya dengan pencarian jurnal dan penelitian yang relevan secara online pustakawan selalu standby untuk membantu proses tersebut. Ketika mahasiswa merasa kesulitan dalam mencari literasi digital tersebut, mahasiswa dapat secara langsung meminta bantuan kepada pustakawan. Pustakawan akan memberikan informasi yang dibutuhkan mahasiswa baik itu berupa link atau website yang bisa digunakan untuk mengakses literasi digital, cara mengakses literasi digital, rekomendasi buku sumber yang dapat dijadikan bahan kajian untuk penelitian.

\section{SIMPULAN}

Berdasarkan data dan pembahasan tersebut dapat disimpulkan bahwa dari segi kelengkapan koleksi buku, ruang baca PGSD telah dapat memenuhi kebutuhan buku sumber untuk proses penyusunan skripsi mahasiswa. Koleksi buku di ruang baca PGSD jika dinyatakan dalam angka mencapai $70 \%$ dari buku sumber yang dibutuhkan mahasiswa dalam penyusunan skripsi.

Selain koleksi buku, hal lain yang turut mendukung proses penyusunan skripsi adalah akses mahasiswa terhadap jurnal nasional dan internasional, literasi digital 
serta pelayanan yang baik dari pustakawan. Menurut data dari responden, aspek tersebut sudah memuaskan mahasiswa. Fasilitas hotspot, sistem OPAC dan pelayanan prima dari pustakawan mampu memberikan fasilitas yang memadai melengkapi koleksi buku yang masih terbatas.

Dengan tercapainya prestasi gemilang tersebut, yakni ruang baca PGSD mendapat predikat memuaskan dari mahasiswa, tidak menutup peluang bagi pengelola ruang baca PGSD untuk mengembangkan fasilitas yang ada. Seperti saran yang diberikan oleh responden saat wawancara bahwa ruang baca PGSD masih sangat perlu untuk menambah koleksi buku sumber guna mendukung proses penyusunan skripsi mahasiswa. Adanya penambahan koleksi buku sumber tersebut dapat memperluas bidang penelitian skripsi mahasiswa baik jenis penelitian PTK, kualitatif maupun kuantitatif.

DAFTAR PUSTAKA

Berawi, I. (2012). Mengenal Lebih Dekat Perguruan Tinggi. Jurnal Iqra', 06 (01), 59. Diakses pada tanggal 12 Oktober 2018, dari: http://repository.uinsu.ac.id/690/1/iqra\%27\%202012\%20vol.06\%20no.\%2001\%20 -\%20Copy\%20\%287\%29.pdf.

Tsabit, D.I. (2008). Kelayakan Perpustakaan Sebagai Sumber Belajar di Perguruan Tinggi. Jurnal lqra', 02 (02), 87-88. Diakses pada tanggal 12 Oktober 2018, dari: http://download.portalgaruda.org/article.php?article=298742\&val=7280\&title $=K E L$ AYAKAN\%20PERPUSTAKAAN\%20SEBAGAI\%20SUMBER\%20BELAJAR\%20D I\%20PERGURUAN\%20TINGGI.

Kurniawan, T. (2016). Peran Perpustakaan Perguruan Tinggi dalam Mengembangkan Repositori Institusi. Pustakaloka, 8 (2), 239-240. Diakses pada tanggal 12 Oktober 2018, dari: http://jurnal.stainponorogo.ac.id/index.php/pustakaloka/article/download/683/535. 